\title{
Volume replacement with coconut water in rats with hemorrhagic shock
}

\section{Reposição volêmica com água de coco em ratos com choque hemorrágico}

Domitila Costa de Farias, Juliana Câmara Mariz, Paula de Medeiros Nacácio Silva, Vanessa de Fátima Lima Paiva Medeiros, Robson de Macedo Filho, Marília Daniela Ferreira de Carvalho, Irami Araújo-Filho, Amália Cínthia Meneses Rêgo, Ítalo Medeiros Azevedo, Aldo Cunha Medeiros

\footnotetext{
Research performed at Nucleus for Experimental Surgery, Federal University of Rio Grande do Norte (UFRN), Brazil.

Financial support: CNPq.

Conflict of interest: none

Correspondence address: Aldo Cunha Medeiros, Department of Surgery, Federal University of Rio Grande do Norte, at Av. Nilo Peçanha 620, Natal, RN, Brazil, Email: aldo@ufrnet.br Submitted: 04 April 2014. Accepted, after review: 03 July 2014.
}

\begin{abstract}
Purpose: Hemorrhagic shock+trauma is the third leading cause of death worldwide, supported by its frequency, severity and ability to induce systemic inflammatory responses and damage a number of organs. Currently, there is not an ideal fluid for volume replacement. There is relevant knowledge regarding the nutritional composition of coconut water $(\mathrm{CW})$, but studies regarding its use for resuscitation in cases of hemorrhagic shock are lacking. The aim of this study is to evaluate the efficacy of modified coconut water (3\% sodium) for resuscitation in hemorrhagic shock in an experimental model in rats. Methods: Wistar rats weighing 250-300g were used. In group $1(n=6)$ shock + coconut water (CW); group $2(n=6)$ shock + fresh whole blood (FWB); group $3(n=6)$ shock+saline $0.9 \%(S)$. At the end of the experiment, levels of TNF, IL-1, IL-2, C-reactive Protein, AST, ALT, urea, creatinine were measured. Results: All animals survived the procedures and tests by the end of the experiment. There was a significant reduction in liver function tests (ALT and AST), urea and creatinine in animals treated with CW, compared with those treated with FWB and $S(p<0,05)$. However, no significant differences were observed when the parameters were compared between FWB and saline ( $p>0.05)$ groups. The TNF- $\alpha, \mathrm{IL}-1 \beta$ and IL-2 expression were significantly lower in rats treated with $\mathrm{CW}$ than in rats treated with FWB and $S(p<0.05)$. In animals treated with $C W$ the mean level of $C$-reactive protein was lower than in saline rats $(P<0.05)$. Conclusion: Our results demonstrate that, in rats with hemorrhagic shock, i.v. coconut water administration preserved renal and hepatic function, and was superior to fresh whole blood and saline with regard to proinflammatory cytokine expression.
\end{abstract}

Keywords: Hemorrhagic shock. Coconut water. Whole blood. Resuscitation. 
Volume replacement with coconut water in rats with hemorrhagic shock

Farias, DC, et al

\section{RESUMO}

Introdução: O choque hemorrágico+trauma é a terceira principal causa de morte no mundo, devido à frequência, gravidade e capacidade de induzir resposta inflamatória sistêmica e lesar vários órgãos. Atualmente, não existe um fluido ideal para a reposição volêmica no choque. Há conhecimento relevante sobre a composição nutricional de água de coco (AC), mas estudos sobre o seu uso para a reanimação em casos de choque hemorrágico não existem atualmente. O objetivo deste estudo é avaliar a eficácia da água de coco modificada (3\% de sódio) para reanimação em modelo experimental de choque hemorrágico em ratos. Métodos: Foram utilizados ratos Wistar com peso entre 250-300g. No grupo $1(n=6)$ choque+água de coco (AC); grupo $2(n=6)$ choque+ sangue total fresco (STF); grupo 3 ( $n=$ 6) choque+salina a $0,9 \%(\mathrm{~S})$. No final do experimento, os níveis de TNFa, IL-1 $\beta$, IL-2, proteína C-reactiva, AST, ALT, ureia, creatinina foram medidos. Resultados: Todos os animais sobreviveram aos procedimentos e testes. Houve uma redução significativa nas provas de função hepática (ALT e AST), ureia e creatinina em animais tratados com AC, em comparação com os tratados com STF e $S(p<0,05)$. No entanto, não foram observadas diferenças significativas quando os parâmetros foram comparados entre STF e grupo salina ( $p>0,05)$. A expressão de TNF- $\alpha$, IL-1 $\beta$ e IL-2 foi significativamente mais baixa nos ratos tratados com AC do que nos tratados com STF e $S(p<0,05)$. Nos animais tratados com a AC a média do nível de proteína C-reactiva foi mais baixa do que nos ratos tratados com salina $(P<0,05)$. Conclusão: Nossos resultados demonstram que, em ratos com choque hemorrágico, a administração i.v. de água de coco preservou a função renal e hepática, e foi superior ao sangue total fresco e solução salina na expressão de citocinas pró-inflamatórias.

Descritores: Choque hemorrágico. Água de coco. Sangue. Salina. Ressuscitação.

\section{INTRODUCTION}

Trauma followed by hypovolemic shock is the third leading cause of death in the world $^{1-3}$ and is the leading cause of death in people aged below 45 years ${ }^{4}$. A large number of traumatized individuals, present in emergency rooms, have been stricken with hypovolemic shock. In such cases, a large volume of isotonic saline solution is nowadays the standard treatment for hypovolemic shock ${ }^{5}$. However, there are special situations where the efficiency of replacement with large fluid volumes is limited and controversial. In prehospital care, especially when dealing with polytrauma, the infusion of large volumes of saline is often insufficient ${ }^{5}$.

Due to its limited efficacy, different types of volume replacement solutions have been evaluated over the past 10 years to ensure best plasma expansion for patients. In the $80 \mathrm{~s}$, a study showed that hypertonic saline significantly improved hemodynamic parameters of the shock patients, even when small volumes were infused ${ }^{6}$. During the following years, other studies have shown that hypertonic solutions significantly increased blood pressure and cardiac output ${ }^{7}$, reversing hypovolemic shock without compromising the cardiopulmonar function ${ }^{8.9}$.

Moreover, it is also known that replacement of plasma volume using isotonic solutions may induce hemodilution, which is well tolerated by healthy patients. Immediate effects may 
Volume replacement with coconut water in rats with hemorrhagic shock

Farias, DC, et al

depend on the duration and intensity of bleeding. Patients often come to the emergency room with hemodilution due to the loss of large volumes of blood. The possible influence of this condition on the patient's response to treatment with fluid replacement and its evolution is not well determined. Furthermore, continuous bleeding in these patients requires additional treatment.

Quick removal from the scene to a medical trauma center proved to be of extreme importance for severely injuried patients ${ }^{11}$, and isotonic fluids are frequently infused in prehospital care. However, the infused volume is usually unable to compensatewhole lost blood $^{11}$. The attempt to restore blood volume with crystalloid solutions may aggravate the situation, decreasing the oxygen supply, increasing mortality ${ }^{12-15}$. The use of small volumes of hypertonic solutions have been proposed to minimize this problem and treat hypovolemic shock $^{9,11}$. Controversial remains about what replacement solution to use, and some statistics on the overall mortality rate has been $50 \%$.

In the present study, we tested an alternative for volume replacement in hypovolemic shock model using modified coconut water. This is a solution with multiple components containing electrolytes, carbohydrates, proteins, lipids, antioxidants, and trace elements. Coconut water begins to be produced within the fruit one month after the inflorescence. The ideal time for harvesting the fruit 6 months, when much water is present, corresponding to $25 \%$ of the weight of the fruit. In this phase, the liquid has a nice taste and is rich in nutrients, with low lipid content. Some authors have studied coconut water nutritional composition. Santoso et $\mathrm{al}^{16}$ reported detailed information on the presence of vitamins, sugars, organic acids, fatty acids, aminoacids, electrolytes and minerals in Cocus nucifera $L$. Aleixo et $\mathrm{al}^{17}$ determined the content of selenium, using atomic absorption spectrometry. Another relevant characteristic of coconut water is its antioxidant activity ${ }^{18-20}$. Metals and trace elements in small dosages were determined, with potential for use in intravenous hydration and to replace or supplement parenteral nutrition solutions ${ }^{21}$. The liquid was still reported as rehydrating in cases of diarreia ${ }^{22}$.

Campbell-Falck et al reported a case of intravenous hydration at Salomon Island and described its use during World War $\|^{23}$. The electrolyte composition of the fruit at 6 months has almost the same content of potassium, calcium, magnesium and chlorine as intracellular fluid. Coconut water has significantly less sodium then human plasma ${ }^{24}$. Although it can't be considered the ideal solution for resuscitation, their successful use has been reported in some cases $^{25}$. Its intravenous use does not interfere with the mechanisms of hemostasis and coagulation $^{26}$.

Considering the fact that the known solutions for volume replacement are not ideal for treatment of shock and blood loss, and knowing the relevance of hemorrhagic shock as a common and serious condition, this experimental study aimed to explore the potential of coconut water as solution for volume replacement. Despite the potentially favorable composition of coconut water, well-conducted studies are very scarce in the literature regarding its use for volume replacement in cases of hemorrhagic shock. Thus, we evaluated the efficacy of modified coconut water as a potential solution for fluid resuscitation. The objective of this study was to evaluate the efficacy of intravenous modified coconut water compared with fresh blood and saline (sodium chloride $0.9 \%$ ), as resuscitation fluids in the treatment of hypovolemic shock in an experimental model in rats. We evaluate survival, metabolic parameters and pro-inflammatory cytokines. 
Volume replacement with coconut water in rats with hemorrhagic shock

Farias, DC, et al

\section{METHODS}

This protocol was submitted to the institutional Ethics Committee for Animal Use from UFRN. Care in the use of animals followed existing rules in Brazilian law for scientific use of animals (Law No. 1179/2008). The study was performed in the Nucleus of Experimental Surgery-UFRN.

Animal model of hypovolemic shock was used to compare the effectiveness of modified coconut water, fresh whole blood and $0.9 \%$ saline as resuscitation solutions for hemorrhagic shock. Young, healthy Wistar rats weighing between 250 and $300 \mathrm{~g}$ were used. They were fasted for 12 hours before being anesthetized for the experiment.

Rats were anesthetized with ketamine $(50 \mathrm{mg} / \mathrm{kg})$ and xylazine $(20 \mathrm{mg} / \mathrm{kg})$ intraperitoneal, readministered periodically if necessary, until the end of the experiments. After stabilization of anesthesia, invasive monitoring was installed. The femoral vein and contralateral artery were dissected. 24G silicone cannulae were inserted into the femoral artery to monitor mean arterial blood pressure and the femoral vein for blood drainage and subsequent fluid replacement. These procedures were performed using a surgical microscope DFV, Sao Paulo, Brazil (10X). Blood was drained through the femoral vein to stabilize the mean arterial pressure around $35 \mathrm{mmHg}$.

The shock was installed in all animals and maintained for a period of $60 \mathrm{~min}$. After this period, the animals received fluid resuscitation over $10 \mathrm{~min}$. The volume replacement was equal to the lost blood volume. For each solution infused for volume replacement was a group of 6 animals. In group $1(n=6)$, shock + fresh whole blood; group $2(n=6)$ shock + coconut water; group $3(n=6)$ shock + saline $0.9 \%$. The animals were kept in a controlled microenvironment in hot plate at $37^{\circ} \mathrm{C}$ (Insight, São Paulo, Brazil), and anesthetized by the end of the experiment.

Coconut water was obtained from coconut specimens Cocus nucifera, 6 months (from the inflorescence until harvest fruits). Using sterile technique, coconut water was removed immediately prior to administration in animals and modified appropriately to achieve 3\% sodium level. The $\mathrm{pH}$ of coconut water was adjusted to 7.4 with sodium bicarbonate $10 \%$, prior to intravenous infusion, using pHameter (Micronal, São Paulo, Brazil). Then, the solution was filtered through a sterile filter. Heparinized fresh blood was harvested from additional rats, and infused immediately after the shock period (60 min.); 0.9\% saline was from B. Braun, Rio de Janeiro, Brazil. All solutions were infused through an infusion pump (B. Braun, Rio de Janeiro, Brazil), calculating the volume to be used always for 10 minutes at constant infusion. During the fluid replacement, solutions were heated to $37^{\circ} \mathrm{C}$.

The experimental protocol included assessment to laboratory parameters six hours after resuscitation. The total observation period for measurement of survival was 6 hours, at intervals every 1 hour.

About $5 \mathrm{ml}$ of blood were collected by cardiac puncture from survivor animals at the end of the experiment for determination of serum levels of TNFa, IL1 $\beta, I L-2, A S T, A L T$, urea, creatinine, and protein $C$ reactive. Serum samples were collected in dry tubes, centrifuged and stored in a freezer at $-40^{\circ} \mathrm{C}$ until the dosages. The determination of the parameters was performed using specific commercial kits and processed according to the manufacturers instructions. After collection, the animals were euthanazed by an overdose of anesthetic (Thiopental $100 \mathrm{mg} / \mathrm{kg}$ intraperitoneal). 
Volume replacement with coconut water in rats with hemorrhagic shock

Farias, DC, et al

\section{Statistical analysis}

Data were stored and analyzed statistically by the BioEstast 5.0 software, the significance of differences between groups was calculated by one-way ANOVA, followed by method of multiple comparisons Tukey test. Results were considered statistically significant when $p<0.05$.

\section{RESULTS}

We applied three resuscitation strategies, fresh whole blood (FWB), cocconut wather (CW) and saline (S), to a pressure-controlled rat model of hemorrhagic shock. Mean hepatic and renal evaluation was different between animals resuscitated with CW, FWB and S after hemorrhagic shock and resuscitation period.

All animals survived the procedures and tests by the end of the experiment. There was a significant reduction in liver function tests (ALT and AST), urea and creatinine in animals treated with CW, compared with those treated with FWB and $S(p<0,05)$. These data are summarized in Table 1. However, no significant differences were observed when the parameters were compared between FWB and $S(p>0.05)$ groups.

Table 1 - Results and statistical tests related to biochemical analysis

\begin{tabular}{l|cc|c|c}
\hline \multirow{2}{*}{$\begin{array}{c}\text { Biochemical } \\
\text { parameters }\end{array}$} & \multicolumn{3}{|c|}{ Grupo } & \multirow{2}{*}{ p-value ${ }^{(1)}$} \\
\cline { 2 - 4 } & $\begin{array}{c}\text { Fresh whole } \\
\text { blood }\end{array}$ & Coconut water & Saline & \\
\hline AST (U/L) & $59.60 \pm 5.02$ & $22.82 \pm 3.14^{*}$ & $48.81 \pm 3.94$ & 0.03 \\
ALT (U/L) & $47.50 \pm 5.68$ & $25.67 \pm 2.94^{*}$ & $54.63 \pm 4.90$ & $<0.05$ \\
Urea (mg/dL) & $48.40 \pm 7.34$ & $17.67 \pm 3.78^{*}$ & $38.63 \pm 4.78$ & $<0.05$ \\
Creatinine (mg/dL) & $1.54 \pm 0.34$ & $0.69 \pm 0.28^{*}$ & $1.82 \pm 0.24$ & $<0.05$ \\
\hline
\end{tabular}

Mean \pm Standard deviation; 1. P-value analysis by ANOVA. * Significant difference comparing with Fresh whole blood and saline groups. (Tukey test)

As a measure of immunological effect, we assessed the expression of TNF- $\alpha, \mathrm{IL}-1 \beta$ and IL-2. The results revealed that the expression of cytokines were significantly lower in rats treated with CW than in animals treated with FWB and $S(p<0.05)$. Data summarized in table 2 . In animals treated with $\mathrm{CW}$ the mean value of $\mathrm{C}$-reactive protein revealed significantly lower than in animals treated with saline $(P<0.05)$. 
Volume replacement with coconut water in rats with hemorrhagic shock

Farias, DC, et al

Table 2 - Results and statistical tests related to analysis of cytokines and C-reactive protein.

\begin{tabular}{l|c|c|c|c}
\hline \multirow{2}{*}{$\begin{array}{c}\text { Cytokine } \\
\text { expression }\end{array}$} & \multicolumn{3}{|c|}{ Group } & \multirow{2}{*}{-value } \\
\cline { 2 - 5 } & Fresh whole blood & Coconut water & Saline & \\
\hline TNF $\alpha(\mathrm{pg} / \mathrm{mL})$ & $27.3 \pm 3.2$ & $22.1 \pm 2,7^{1}$ & $35.7 \pm 5,3$ & 0.04 \\
$\mathrm{IL}-1 \beta(\mathrm{pg} / \mathrm{mL})$ & $25.2 \pm 4.1$ & $14.5 \pm 1.2^{1}$ & $43.1 \pm 4.5$ & $<0.05$ \\
$\mathrm{IL}-2(\mathrm{pg} / \mathrm{mL})$ & $23.1 \pm 5.3$ & $15.1 \pm 2.2^{1}$ & $26.1 \pm 4.1$ & $<0.05$ \\
C-reative Proteine $(\mathrm{mg} / \mathrm{L})$ & $2.5 \pm 0.3$ & $2.2 \pm 0.3^{2}$ & $3.6 \pm 0.5$ & $<0.05$ \\
\hline
\end{tabular}

Mean \pm Standard deviation

P-value analysis by ANOVA. 1. Significant difference comparing with Fresh whole blood and saline groups. 2.

Significant difference comparing with saline group. (Tukey test)

\section{DISCUSSION}

In this study, we compared the effect of resuscitation with fresh whole blood (FWB), coconut wather $(\mathrm{CW})$ or saline $(\mathrm{S})$ solution on the initial inflammatory response to hemorrhagic shock. Hemorrhagic shock promotes a systemic inflammatory response, which contributes to the development of late complications. In some patients, this response initiates an influx of inflammatory cells into the lung, manifested as acute lung injury and acute respiratory distress syndrome, each of which confer significant morbidity and late mortality ${ }^{27}$. Although each resuscitation strategy used in our model prevented hemorrhage-induced mortality, there were significant differences in systemic inflammation (TNFa, II-1 $\beta, \mathrm{IL}-2, \mathrm{C}-$ reactive protein) between rats resuscitated with coconut water, comparing with saline and fresh whole blood. These findings support the concept that conventional fluid resuscitation may prime the inflammatory response for the development of organ injury and late complications.

In the present work coconut water has been modified in its $\mathrm{pH}$ and sodium content and then used intravenously in a group of animals. This group showed the best results in the liver function tests, renal function tests and measurement of pro-inflammatory cytokines and C-reactive protein. Everything suggests that these results were positively influenced by the physicochemical composition of coconut water. Santoso et $\mathrm{al}^{16}$ reported detailed information on the presence of vitamins, sugars, organic acids, fatty acids, amino acids, electrolytes and minerals in Cocus nucifera $L$ water. Aleixo et $\mathrm{al}^{17}$ determined the content of selenium, using atomic absorption spectrometry. Another relevant characteristic of coconut water is its antioxidant activity ${ }^{18-20}$. Metals and trace elements were determined, with potential for use in intravenous hydration or supplement parenteral solutions ${ }^{21}$.

In other animal models, lactate Ringer has been shown to increase systemic inflammation when compared with experimental fluid resuscitation strategies including hypertonic saline and colloids ${ }^{28,29}$. A comparison of the effects on inflammation, hepatic and renal function between fresh whole blood and coconut water resuscitation after hemorrhagic shock has not previously been performed, and the relationship between systemic inflammation and renal/hepatic injury has not been fully evaluated. In our study, we demonstrated that resuscitation with modified coconut water after hemorrhagic shock resulted in less systemic inflammation when compared with fresh whole blood resuscitation and crystalloid saline. This was evident by decreased serum levels of TNFa, II-1ß, IL-2 and 
C-reactive protein in rats receiving coconut water. Each of these mediators seems to be important in pathogenesis of the inflammatory response to hemorrhagic shock.

TNF is considered as pivotal inflammatory agent in hemorrhage. TNFa diffuses in the bloodstream and initiates a fatal cardiovascular collapse ${ }^{30}$. TNFa is a sufficient and necessary mediator of hemorrhagic shock, because (i) it is detected to be high in patients and experimental models of hemorrhagic shock; (ii) it may contribute to the lethality of hemorrhagic shock; (iii) its neutralization attenuates cardiovascular shock. TNFa plays an important role in excessive autodestructive inflammation and may finally induce multiple organ failure through the activation of neutrophils ${ }^{31}$. TNFa is known to trigger the release of other proinflammatory cytokines, such as IL-1 $\beta$ and IL- $6^{32}$. In addition, TNF $\alpha$ has much more potency than that of other cytokines in activation of neutrophils ${ }^{33}$. Many experimental studies have focused on the production of TNFa in severe hemorrhage.

The strong ion difference of $0.9 \%$ saline is zero, with the result that the administration of large volumes of saline results in a hyperchloremic metabolic acidosis ${ }^{34}$. Adverse effects such as immune ${ }^{35}$ and renal $^{36}$ dysfunction have been attributed to this phenomenon, although the clinical consequences of these effects is unclear ${ }^{37}$.

In our study we observed a significant difference on the renal function tests comparing saline and coconut water resuscitation. Concern about sodium and water overload associated with saline resuscitation has resulted in the concept of "small volume" crystalloid resuscitation with the use of hypertonic saline (3\%, $5 \%$, and $7.5 \%)$ solutions. In our study we supplemented coconut water with $3 \%$ sodium. However, the early use of hypertonic saline for resuscitation, particularly in patients with traumatic brain injury, has not improved either short-term or longterm outcomes ${ }^{38}$. Crystalloids with a chemical composition that approximates extracellular fluid have been termed "balanced" or "physiologic" solutions and are derivatives of the original Hartmann's and Ringer's solutions. However, none of these solutions are either truly balanced or physiologic ${ }^{39}$. Given the concern regarding an excess of sodium and chloride associated with normal saline, balanced salt solutions are increasingly recommended as first-line resuscitation fluids in patients undergoing surgery, patients with trauma, and patients with diabetic ketoacidosis ${ }^{40}$. Resuscitation with balanced salt solutions is a key element in the initial treatment of patients with burns, although there is increasing concern about the adverse effects of fluid overload, and a strategy of "permissive hypovolemia" in such patients has been advocated ${ }^{41}$.

According to the above concepts, we can assume that coconut water adjusted to $\mathrm{pH}$ 7.0 and sodium content of $3 \%$, has the characteristics of a balanced crystalloid solution. The supposed advantage of this solution is the presence of antioxidants, trace elements and other therapeutic substances. In conclusion, our results demonstrated that, in rats with hemorrhagic shock, i.v. coconut water administration positively influenced renal and hepatic function, and was superior to fresh whole blood and saline with regard to pro-inflammatory cytokine expression.

\section{REFERENCES}

1. Compton C, Rhee R. Peripheral vascular trauma. Perspect Vasc Surg Endovasc Ther. 2005;17:297-307.

2. Macho JR, Krupski WC, Lewis Jr FR. Management of the injured patient. In: Way LW, Dowerty GM. Current surgical diagnosis and treatment. 11ed. New York: McGraw-Hill. 
Volume replacement with coconut water in rats with hemorrhagic shock

Farias, DC, et al

2003; 230-66.

3. Melniker LA, Leibner E, McKenney MG, Lopez P, Briggs WM, Mancuso CA. Randomized controlled clinical trial of point-of-care, limited ultrasonography for trauma in the emergency department: the first sonography outcomes assessment program trial. Ann Emerg Med. 2006;48:227-39.

4. ATLS Home. Chicago: American College of Surgeons; 1996. Atualizada em: 31 jan. 2011. Acesso em: 21 abr. 2013. Disponível em: <http://www.facs.org/trauma/atls/index.html>.

5. Rocha-e-Silva M, Poli de Figueiredo LF. Small volume hypertonic resuscitation of circulatory shock. Clinics. 2005;60:159-72.

6. Velasco IT, Pontieri V, Rocha e Silva M, Lopes OU. Hyperosmotic $\mathrm{NaCl}$ and severe hemorrhagic shock. Am J Physiol. 1980;239:664-73.

7. Nakayama S, Sibley L, Gunther RA, Holcroft JW, Kramer GC. Small volume resuscitation with hypertonic saline $(2400 \mathrm{mOsm} / \mathrm{litter})$ during hemorrhagic shock. Circ Shock. 1984;13:149-59.

8. Layon J, Duncan D, Gallaghar TJ, Banner MJ. Hypertonic saline as a resuscitation solution in hemorrhagic shock: effect on extravascular lung water and cardiopulmonary function. Anesth Analg. 1987;66:154-8.

9. Younes RN, Bechara MJ, Langer B, Aun F, Birolini D, Kusniek S, Guimarães PCM, Puech Leão LE. Prevention of aortic declamping shock with hypertonic $7.5 \% \mathrm{NaCl}$ solution in abdominal aneurysmectomy of the aorta. Braz J Med Biol Res. 1986;19:1417.

10. Younes RN, Rogatko A, Brennan MF. The hemodynamic response to hemorrhage in tumor-bearing animals. Surgery. 1991;110:508-13.

11. Younes RN, Aun F, Accioly CQ, Casale LP, Szajnbok I, Birolini D. Hypertonic solutions in the treatment of hypovolemic shock: a prospective, randomized study in patients admitted to the emergency room. Surgery. 1992;111:380-5.

12. Marshall Jr HP, Capone A, Courcoulas AP, Harbrecht BG, Billiar TR, Udekwu AO, Peitzman AB. Effects of hemodilution on long-term survival in an uncontrolled hemorrhagic shock model in rats. J Trauma. 1997;43:673-8.

13. Bickell WH, Bruttig SP, Millnamow GA, O'Benar J, Wade CE. The detrimental effects of intravenous crystalloid after aortotomy in swine. Surgery. 1991;110:529-36.

14. Singh G, Chaudry KI, Chaudry IH. Crystalloid is as effective as blood in the resuscitation of hemorrhagic shock. Ann Surg. 1992;215:377.

15. Burris D, Rhee P, Kaufmann C, Pikoulis E, Austin B, Eror A, Debraux S, Guzzi L, Leppaniemi. Controlled resuscitation for uncontrolled hemorrhagic shock. J Trauma. 1999;46:216-19.

16. Santoso U, Kubo K, Ota T, Tadokoro T, Mackawa A. Nutrient composition of kopyor coconut (cocos nucifera L.). Food Chem. 1996; 57: 299-304.

17. Aleixo PC, Nóbrega JA, Santos D, Muller PCS. Determinação direta de selênio em água de coco e em leite de coco utilizando espectrometria de absorção atômica com atomização eletrotérmica em forno de rafite. Quim Nova 2000; 23:310-12.

18. Leong LP, Shui G. An investigation of antioxidant capacity of fruits in Singapure market. Food Chem. 2002; 76: 69-75.

19. Wagner $\mathrm{KH}$, Derkits $\mathrm{S}$, Herr M, Schuh $\mathrm{H}$, Elmadfa I. Antioxidative potential of melanoidins isolated from a roasted glucose-glycine model. Food Chem. 2002; 78: 37582.

20. Fonseca AM, Bizerra ACM, Souza JSN, Monte FJQ, Oliveira MCF, Mattos MC, Cordell 
GA, Braz-Filho R, Lemos TLG. Constituents and antioxidant activity of two varieties of coconut water (Cocos nucifera L.) Braz J Pharmacogn. 2009;19(1B): 193-198.

21. Petroianu GA, Kosanovic M, Shehatta IS, Mahgoub B, Saleh A, Maleck WH. Traces and minor element contents in coconut water. J Trace Element Exp Med. 2004; 17: 273-76.

22. Vigliar R, Sdepanian VL, Fagundes-Neto U. Biochemical profile of coconut water from coconut palms planted in an inland region. J Pediatr. 2006;82:308-12.

23. Campbell-Falck D, Thomas T, Falck TM, Tutuo N, Clem K. The intravenous use of coconut water. Am J Emerg Med. 2000;18:108-11.

24. Richter EM, Jesus DP, Munoz RAA, Lago CL, Angnes L. Determination of Anions, Cations, and Sugars in Coconut Water by Capillary Electrophoresis. J Braz Chem Soc. 2005;16:1134-9.

25. Olurin EO, Durowoju JEO, Bassir O. Intravenous cocconut water therapy in surgical practice. West Afr Med J. 1972; 21:124-31.

26. Pummer S, Heil P, Maleck W, Petroianu G. Influence of coconut water on hemostasis. Am J Emerg Med. 2001;19:287-9.

27. Puneet $P$, Moochhala $S$, Bhatia $M$. Chemokines in acute respiratory distress syndrome. Am J Physiol Lung Cell Mol Physiol. 2005;288:L3-L15.

28. Vincenzi R, Cepeda LA, Pirani WM, Sannomyia P, Rocha-E-Silva M, Cruz RJ Jr. Small volume resuscitation with $3 \%$ hypertonic saline solution decrease inflammatory response and attenuates end organ damage after controlled hemorrhagic shock. Am J Surg. 2009;198:407- 14.

29. Alam HB, Stanton K, Koustova E, Burris D, Rich N, Rhee P. Effect of different resuscitation strategies on neutrophil activation in a swine model of hemorrhagic shock. Resuscitation. 2004;60:91-9.

30. Ulloa L, Messmer D. "High-mobility group box 1 (HMGB1) protein: friend and foe," Cytok Growth Factor Rev. 2006;17:189-201.

31. Donnahoo K K, Shames B D, Harken A H, Meldrum D R. "The role of tumor necrosis factor in renal ischemia-reperfusion injury," J Urol. 1999;162:196-203.

32. Suitters A J, Foulkes R, Opal S M, et al. Differential effect of isotype on efficacy of antitumor necrosis factor $\alpha$ chimeric antibodies in experimental septic shock. J Exper Med. 1994;179:849-56.

33. Suzuki K, Hino $M$, Kutsuna $\mathrm{H}$, et al. Selective activation of p38 mitogen-activated protein kinase cascade in human neutrophils stimulated by IL-1 $\beta$. J Immunol. 2001;167:5940-7.

34. Morgan TJ, Venkatesh B, Hall J. Crystalloid strong ion difference determines metabolic acid-base change during acute normovolaemic haemodilution. Intensive Care Med 2004;30:1432-7.

35. Kellum JA, Song M, Li J. Science review: extracellular acidosis and the immune response: clinical and physiologic implications. Crit Care. 2004;8:331-6.

36. Hadimioglu N, Saadawy I, Saglam T, Ertug Z, Dinckan A. The effect of different crystalloid solutions on acid-base balance and early kidney function after kidney transplantation. Anesth Analg. 2008;107:264-9.

37. Handy JM, Soni N. Physiological effects of hyperchloraemia and acidosis. Br J Anaesth. 2008;101:141-50.

38. Cooper DJ, Myles PS, McDermott FT, et al. Prehospital hypertonic saline resuscitation of patients with hypotension and severe traumatic brain injury: a randomized controlled trial. JAMA. 2004;291:1350-7.

39. Guidet B, Soni N, Della Rocca G, et al. A balanced view of balanced solutions. Crit Care. 2010;14:325-9. 
40. Chua HR, Venkatesh B, Stachowski E, et al. Plasma-Lyte 148 vs $0.9 \%$ saline for fluid resuscitation in diabetic ketoacidosis. J Crit Care. 2012;27:138-45.

41. Arlati S, Storti E, Pradella V, Bucci L, Vitolo A, Pulici M. Decreased fluid volume to reduce organ damage: a new Approach to burn shock resuscitation? A preliminary study. Resuscitation. 2007;72:371-8. 